\title{
Improving the academic self-efficacy of middle school girls toward the study of mathematics through the use of theatrical infusion
}

\author{
Aimee L. Richards \\ West Virginia University
}

Follow this and additional works at: https://researchrepository.wvu.edu/etd

\section{Recommended Citation}

Richards, Aimee L., "Improving the academic self-efficacy of middle school girls toward the study of mathematics through the use of theatrical infusion" (2010). Graduate Theses, Dissertations, and Problem Reports. 2972.

https://researchrepository.wvu.edu/etd/2972

This Dissertation is protected by copyright and/or related rights. It has been brought to you by the The Research Repository @ WVU with permission from the rights-holder(s). You are free to use this Dissertation in any way that is permitted by the copyright and related rights legislation that applies to your use. For other uses you must obtain permission from the rights-holder(s) directly, unless additional rights are indicated by a Creative Commons license in the record and/ or on the work itself. This Dissertation has been accepted for inclusion in WVU Graduate Theses, Dissertations, and Problem Reports collection by an authorized administrator of The Research Repository @ WVU.

For more information, please contact researchrepository@mail.wvu.edu. 
Improving the Academic Self-Efficacy of Middle School Girls Toward the Study of Mathematics Through the Use of Theatrical Infusion

\author{
Aimee L. Richards \\ Dissertation \\ Submitted to the \\ College of Human Resources and Education \\ at \\ West Virginia University \\ in partial fulfillment of the requirements for the degree of \\ Doctor of Education \\ in Educational Psychology
}

Neal Shambaugh, Ph.D.

Daniel Hursh, Ph.D.

Joanne Siegrist, M.F.A.

Jay Malarcher, Ph.D.

Richard T. Walls, Ph.D., Committee Chair

Morgantown, West Virginia

2010

Keywords: self-efficacy, integrated curriculum, infusion, mathematics instruction 


\begin{abstract}
Improving the Academic Self-Efficacy of Middle School Girls Toward the Study of Mathematics Through the Use of Theatrical Infusion
\end{abstract}

Aimee L. Richards

The purpose of this study was to determine the impact of theatrical infusion on the academic self-efficacy toward the study of mathematics in middle school girls. A group of middle school girls participated in a program entitled Starring...Math. This five session program presented mathematical concepts through the use of theatrical infusion. The group of participants was composed of twenty-one girls in sixth, seventh and eighth grades.

Part I: Everyday Math Tasks of the Mathematics Self-Efficacy Scale (Betz \& Hackett, 1989) was administered at three occasions: (1) prior to the start of the program, (2) at the end of the program and, (3) two weeks after the end of the program. Participants were asked to rate their self-efficacy toward a variety of math tasks on a Likert Scale (0-9). Part I: Everyday Math Tasks is comprised of eighteen scale items. The items were divided into two groups. One group was comprised of items related to material covered in the program. One group was comprised of items relating to material not covered in the program.

The study examined the change in score for Covered and Uncovered Scale-Items. There was a statistically significant increase in self-efficacy rating from Pre-Test occasion to Post-Test occasion for both Covered and Uncovered Scale-Items. There was no significant decrease in self-efficacy rating from Post-Test to Follow-Up for either group of scale-items. 


\section{ACKNOWLEDGEMENTS}

The author wishes to express her sincere appreciation to her Doctoral Committee for their patience and contributions to this document. Special thanks is extended to Dr. Richard Walls for his caring guidance throughout. This accomplishment would not have been possible without his encouragement, help and support. The author wishes to express love and appreciation to her family for their support throughout this long journey.

This work is dedicated to Birkely and Brynly. Everything endeavored and accomplished is done so for them. 


\section{TABLE OF CONTENTS}

CHAPTER

PAGE

1 INTRODUCTION AND LITERATURE REVIEW

Self-Efficacy.....................................................

The Way Girls Learn...............................................

New Paradigm for Instruction.................................... 6

Drama..................................................................

Conclusion...................................................... 16

2. METHOD

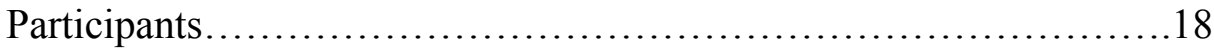

Research Design.................................................. 18

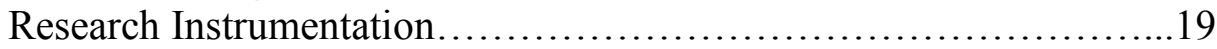

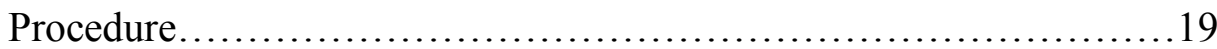

Data Analysis....................................................

3. RESULTS

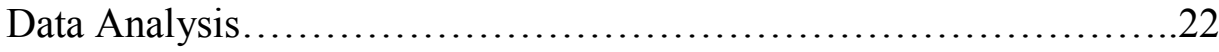

4. DISCUSSION AND CONCLUSIONS

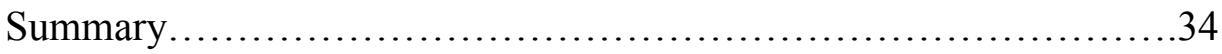

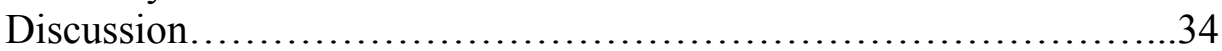

Implications for Future Research.................................37

Conclusions....................................................... 38

\section{APPENDICES}

APPENDIX A: Mathematics Self-Efficacy Scale....................47

APPENDIX B: Starring...Math....................................52 


\section{LIST OF TABLES}

TABLE

PAGE

1. The Mathematics Self-Efficacy Scale-Item Classification

2. Means and Standard Deviations for Covered vs. Uncovered

Scale-Items crossed with Pre vs. Post vs. Follow-up Repeated Measures

3. Analysis of Variance for Covered vs. Uncovered Scale-Items crossed with Pre vs. Post vs. Follow-Up Testing 
Academic Self-Efficacy vi

\section{LIST OF FIGURES}

FIGURE $\quad$ PAGE

1. Mean Differences in Covered Items vs. Uncovered Items

33

at Each Testing Occasion 


\section{CHAPTER 1}

Introduction and Literature Review

In 1957, Sputnik shot into the cosmos, and the United States fell behind in the space race. Since then, science and mathematics have been at the forefront of the American education system. Goals for American dominance have been set repeatedly, including Goal Five of the National Education Goals which reads, "by the year 2000, United States students will be first in the world in mathematics and science achievement" (Austin, 2005). Math and science are looked upon as the fountain from which come products, services, standards of living, economic and military security, and the technological creativity American companies need to compete in the global marketplace (National Commission on Mathematics and Science Teaching for the $21^{\text {st }}$ Century, 2000). The year 2000 has come and gone, and still the United States is far from international dominance in math and science. According to the 2003 Trends in International Mathematics and Science Study, several countries, particularly in Asia, continue to outperform the United States in science and math, fields at the heart of research, innovation, and economic competitiveness (National Commission on Mathematics and Science Teaching for the $21^{\text {st }}$ Century, 2000). Comparative national data for mathematics and science reveal a near-monopoly by Asia in the top-scoring group which included Singapore, Korea, Hong Kong, Taiwan, and Japan. Several European nations cluster below that, and the United States and several other nations are in the next set. There is a considerable spread of scores among nations, with the average scaled scores from eighth-grade mathematics ranging from 605 (Singapore) to 264 (South Africa) (Bybee \& Kennedy, 2005).

There is a far-reaching impact to this failure that grows each year. Jobs requiring science and math skill in the health sciences and computer industries will grow to 5.6 million globally by 
2008. The United States Department of Labor (2000) estimates that postsecondary institutions will have to produce quadruple the number of graduates in these fields to meet the demand. Accelerating technological development and global competition are fueling an unprecedented need for people possessing new and higher skills. Over the past half-century, the ratio of unskilled to skilled jobs has shifted dramatically. Between 1950 and 1997, the proportion of American jobs classified as unskilled dropped precipitously from $80 \%$ to approximately $15 \%$ (Day \& McCabe, 1997).

Gender differences in performance translate into different career trajectories: men are more likely than women to major in mathematics and pursue mathematics or math-intensive careers, such as engineering and computer science (U.S. Department of Education, 2005). The need for knowledge and skill in science and mathematics goes beyond the need for skilled workers and a country's dominance of the world. If necessity is "the mother of invention" then science and math skill is certainly the father. Before invention comes understanding. Science and mathematics give rise to the development of newer and better technologies and problem solving patterns. Where would Sally Ride, Bill Gates, or Neil Armstrong be without a comprehension of science and math? Mathematics and science have become an integral part of routine, daily life. A lack of understanding of scientific and mathematic principles could prevent the understanding of financial reports, medical directions, technological advances, or current political issues such as cloning and global warming.

Knowledge gained from science and mathematics is crucial in today's global, technology-driven market. Domination of United States students in those subjects has become a national priority, yet the female portion of the student population is not playing an adequate role in the equation. Women constitute $51 \%$ of the total population and $45 \%$ of the 
total workforce but only $12 \%$ of all scientists and engineers (National Council for Research on Women, 2001). The under-representation of women is particularly pronounced in the physical sciences. For example, women comprised $8 \%$ of the total of employed engineers, $36 \%$ of mathematical and computer scientists, $27 \%$ of chemists, and $14 \%$ of geologists and geodesists (White, 1992). This uneven gender representation is affecting the United States scientific output and could be a factor in our lack of success in our goal of dominating the rest of the world in this field. In a paper presented by Gerhard Sonnert (1998) of Harvard University for the New York Academy of Sciences conference "Choices and Successes: Women in Science and Engineering," an argument advocating for the value of diversity was offered. Sonnert posited that increasing diversity (in this case, a greater representation of women) in the scientific community will improve the overall quality of science.

\section{Self-Efficacy}

Questioning of the scarcity of women in science-based and mathematics-based careers is not a new endeavor. Alice Rossi posed the question at a conference on women in science at the Massachusetts Institute of Technology in 1965 (Etzkowitz, Kemelgor, \& Uzzi, 2000). Over 40 years later, the question remains largely unanswered. Some still believe a biological difference between males and females accounts for confidence and achievement gaps in science and mathematics. As recently as 2005, claims were being made that lack of aptitude was the reason for the female deficit in science careers. That year Harvard president Lawrence Summers argued that males outperform females in science because of innate biological differences. He went on to explicitly imply that females lacked an intrinsic aptitude for the sciences (Meredith, 2005). Such views are contradicted by evidence. In one study, a group of researchers studied data from more than 7 million students' scores on math exams mandated by the No Child Left Behind Act. They 
found no significant difference in math performance between girls and boys (Hyde, Lindberg, Linn, Ellis, \& Williams, 2008). The National Assessment of Educational Progress reports that achievement scores at the $4^{\text {th }}$ grade, $8^{\text {th }}$ grade, and $12^{\text {th }}$ grade are nearly identical for males and females (Blank \& Langesen, 1999). This focus on aptitude has shifted to attitude toward the study of science and mathematics. Attitude toward mathematics is the most important factor in determining if students continue on in mathematics during the later high school years (Ma \& Willms, 1999).

What is the reason for the development of this negative attitude toward science and mathematics specific to females? The answer may lie in Albert Bandura's theory of selfefficacy. Self-efficacy is defined as people's beliefs about their capabilities to produce designated levels of performance and exercise influence over events that affect their lives (Bandura, 1994). In other words, it is the confidence in oneself to master a task. This is not to say that self-efficacy and self-fulfilling prophecy are the same. Rather, it means that selfperceptions of capability help determine what individuals do with the knowledge and skills they have. More importantly, self-efficacy is a critical determinant of how well knowledge and skill are acquired in the first place (Pajares, 2002). Self-efficacy affects behavior in important ways. People tend to avoid engaging in a task where their efficacy is low, and generally undertake tasks where their efficacy is high. The stronger the perceived self-efficacy, the more vigorous and persistent are people's efforts (Bandura, 1986). Much self-efficacy research now focuses on the gender gap, known as the confidence gap, which exists in the fields of math and science. Researchers have reported interesting, and perhaps troublesome, findings regarding gender differences on academic self-efficacy indexes. Typically, male students express greater confidence in their mathematics and scientific capabilities, even though there are no achievement 
differences (Pajaras, 2002). Research points to the genesis of this trend occurring in the middle school years. In addition to middle school girls beginning to lose their belief in their ability to succeed at math and science, they also begin to dislike the subject matter. In their 2000 report, Trends in Educational Equity of Girls and Women, the National Center for Educational Statistics reported that a nearly equal number of boys and girls in the fourth grade report positive feelings toward math and science. The results are far different by the time children reach the eighth grade. Eighth-grade girls are less likely to think they are good at math or science. Selfperceptions play an important role in science and math achievement, especially for girls. Selfesteem and academic achievement among girls begin to decline during middle-school years (Backes, 1994). In a study investigating the interplay between science self-efficacy, gender, and ninth graders intentions to take science elective courses in high school, significant differences were found between males and females in science self-efficacy and intentionality with males intending to take more science courses than females (Tippins, 1991).

This difference in self-efficacy has a profound impact on achievement. In math and science, a larger proportion of boys than girls receive top scores on the National Assessment of Educational Progress (NAEP), a nationally representative test of specific subject knowledge given to students in the fourth, eighth, and twelfth grades. The gender gap increases with grade level (American Association of University Women, 1998).

\section{The Way Girls Learn}

There is much we know about the way females learn best. Owens and Straton (1980) found that girls prefer cooperation, open-ended and organized activities, while boys prefer competition and individualism. Girls are more successful in math and science programs that incorporate a cooperative, hands-on approach than in programs that stress competition and 
individual learning (National Council for Research on Women, 2001). Girls like to work in cooperative groups and discuss the task at hand (Fennema \& Leder, 1990). An interdisciplinary focus is also important in the education of girls. Teachers should emphasize how math and the sciences can be integrated into other disciplines such as politics or ecology to spark girls' interest (National Council for Research on Women, 2001). This cooperative, interdisciplinary approach is not being used in the vast majority of classrooms in the United States. Most students spend too much of their time memorizing vocabulary. Seldom are students challenged to master the "big" concepts of math and science that make the content powerful and fascinating (National Science Foundation, 1996). Recent Congressional briefings have focused on the state of math and science education in the United States and how it can be improved. While each brought their own perspective on the program, the panelists were in agreement that the focus of the math and science curriculum should be shifted from covering an exhaustive list of content topics to conveying the essence of "scientific thinking" (American Psychological Association, 2006).

\section{New Paradigm for Instruction}

If girls (and the United States) are to reach their full potential in science and mathematics, they must experience the material in a different way. Literature from the preceding sections suggests three avenues for instruction that would benefit girls: (1) collaboration/cooperation, (2) active/experiential learning, and (3) interdisciplinary instruction. In this section, each will be examined.

\section{Collaboration/Cooperation.}

The concept of collaborative learning, the grouping and pairing of students for the purpose of achieving an academic goal, has been widely researched and advocated throughout the professional literature. The term "collaborative learning" refers to an instructional method in 
which students at various performance levels work together in small groups toward a common goal. The students are responsible for one-another's learning as well as their own. Thus, the success of one student helps other students to be successful (Gokhale, 1995).

Cooperative and collaborative learning differ from traditional teaching approaches in that students work together rather than in competition. Research suggests that cooperative and collaborative learning bring positive outcomes such as deeper and more thorough understanding of content, increased overall achievement, improved self-esteem, and higher motivation. Cooperative learning helps students become actively and constructively involved in content, to take ownership of their own learning, and to resolve group conflicts and improve teamwork skills (Educational Broadcasting Corporation, 2004). When compared with other methods and techniques, findings in cooperative learning can be summarized as producing greater learning, enhanced self- concept and esteem, and greater development of prosocial behaviors. In a metaanalysis of the research literature, Johnson, Mariyama, Johnson, Nelson, and Skon (1981) reviewed 122 studies on cooperative learning. Their analysis supports the significant superiority of cooperative/collaborative learning for the promotion of student achievement and productivity.

As stated by Vygotsky (1978), students are capable of performing at higher intellectual levels when asked to work in collaborative situations than when asked to work individually. Group diversity in terms of knowledge and experience contributes positively to the learning process. Bruner (1985) asserted that cooperative learning methods improve problem solving strategies because the students are confronted with different interpretations of the given situation. The peer support system makes it possible for the learner to internalize both external knowledge and critical thinking skills and to convert them into tools for intellectual functioning.

In a study by Gokhale (1995) which examined the effectiveness of individual learning 
versus collaborative learning in enhancing drill-and-practice skills and critical-thinking skills, it was found that students who participated in collaborative learning had performed significantly better on the critical thinking test than students who studied individually. In the study, the collaborative learning medium provided students with opportunities to analyze, synthesize, and evaluate ideas cooperatively. This group interaction helped students to learn from each-other's knowledge, skills, and experiences. The students had to go beyond simple statements of opinion by offering reasons for their judgments and reflecting upon the criteria used in making these judgments. Among the qualitative findings in the study were the following: (1) most of the participants felt that group work helped them to better understand the material and stimulated their thinking process, and (2) the shared responsibility reduced the anxiety associated with problem- solving.

Other studies have examined various factors that might interact with achievement gain in cooperative learning. Okebukola (1986) and Wheeler and Ryan (1973) found that students who preferred cooperative learning learned more in cooperative methods than those who preferred competition. Chambers and Abrami (1991) found that students on successful teams learned more than those on less successful teams.

Active/Experiential Learning.

Active learning refers to techniques where students do more than just listen to a lecture. Students are involved in an activity involving discovering, processing, and applying information. Active learning derives from two basic assumptions: (1) that learning is by nature an active endeavor, and (2) that different people learn in different ways (Meyers \& Jones, 1993). Research shows greater learning when students engage in active learning (McKinney, 2006).

Similarly, experiential learning is described as involving a direct encounter with the 
phenomena being studied rather than merely thinking about the encounter, or only considering the possibility of doing something about it (Borzak, 1981). The work of David Kolb and Roger Fry (Kolb \& Fry, 1975) has provided structure for the study of experiential learning in the form of their experiential learning circle. This circle involves four points: concrete experience, observation and reflection, forming abstract concepts, and testing in new situations.

Kolb's theory of experiential learning has been somewhat controversial. According to Kolb, learning deals with the production of knowledge (Smith, 2001). Kolb stated, "knowledge results from the combination of grasping experience and transforming it" (Kolb, 1984, p. 41). This position could be contrasted with positions such as those of Paulo Freire whose view focuses on the role of praxis in the relationship of learning processes to knowledge. According to this view, learning is not simply action based on experience and reflection. It must involve certain qualities including (1) a commitment to human well being and (2) the search for truth, and respect for others (Smith, 1997).

Throughout history, educational theorists have touted active and experiential learning. John Dewey argued that children must be engaged in an active quest for learning and new ideas. Jean Piaget theorized that experience is necessary for intellectual development (Labinowicz, 1980). One could even look back further to Arisotle who argued, "those with experience succeeded better than those who only had theory" (Kraft, 1995) and to the Chinese proverb, "I hear, I forget. I see, I remember. I do, I understand.”

Contemporary research supports the notion that when students are actively engaged in the learning process, gains are made in achievement and attitude. A 2001 study comparing business students who completed experiential projects involving data collection and inferential analysis with students who received lectures only, indicated that the experiential method resulted in better 
understanding of statistics (Hakeem, 2001). In their report, the National Mathematics Advisory Panel (2008) conducted a metanalysis of literature addressing the question of whether using "real-world" contexts to introduce and teach mathematical topics and procedures is preferable to using more typical instructional approaches. The analysis revealed that if mathematical ideas are taught using "real-world" contexts, then students' performance on assessments involving similar problems is improved.

\section{Interdisciplinary Instruction.}

There are three main models of interdisciplinary education: parallel instruction, crossdisciplinary instruction, and infusion. These are described in terms of arts education by the Consortium of National Arts Education Associations (2002) in their publication, Authentic Connections: Interdisciplinary Work in the Arts. The three can be seen in terms of being on a continuum. Parallel instruction involves agreement between two instructors pertaining to a focus on a common topic or concept. Each teacher focuses on their own specific disciplines, and the students are left to make the connections on their own. A step beyond parallel instruction is cross-disciplinary instruction. This model features a common theme, addressed in two or more subject areas. The connection between the disciplines is made more explicit in cross disciplinary instruction with individual instructors collaborating and working toward making the connections evident to their students. The third, and most interdisciplinary, of these considered models is infusion. This level is the most rare and sophisticated of the three. Students' learning and outcomes in infused approaches are focused on the relationships between and among complimentary subjects (Consortium of National Arts Education Associations, 2002). Because of its rarity and sophistication, research into infusion is not plentiful. The research that does exist is promising. A three-year study entitled Arts Impact Summer School was conducted in 
conjunction with the Tacoma, Washington public schools and was sponsored by the United States Department of Education and the National Endowment for the Arts. This study explored the impact of teaching educationally at-risk elementary students through dance, theater, and visual arts in support and demonstration of shared concepts and understandings in reading, writing, and math. At the end of the summer program, more than $90 \%$ of the students in each grade level performed the learning criteria (Gonzalez, 2006).

\section{Drama}

From the foregoing literature, it could be deduced that a collaborative, experiential, interdisciplinary learning method should be employed to reach the female population during the crucial middle school years in order to ensure equity and diversity in upper level science and mathematics courses, university programs, and the professional world. Such a method may already exist, ready to be adapted to this context. This section will explore the potential of drama as an intervention to the posed problem specifically examining the relationship of drama to (1) student achievement (2) higher- order thinking skills (3) interdisciplinary education (4) self-efficacy, and (5) the collaborative and experiential learning.

\section{Student Achievement and Higher-Order Thinking.}

The critical and higher level thinking skills crucial to scientific and mathematical development are inherent in the dramatic process. Bolton (1985) pointed out that, while much school learning is a collecting of facts, drama can help students reframe their knowledge into new perspectives. Because drama requires students to organize, synthesize, and articulate, it can encourage students to explore, clarify, and elaborate feelings, attitudes, and ideas (Robbins, 1988).

Reconciling conflicting ideas, formulating new and better ideas, and risk taking in terms 
of thought are all important elements of scientific learning. These elements are also typical of arts learning and endeavor. This mix of logical and intuitive thinking is evident in most creative artists as well as scientists (Burton, Horowitz, \& Abeles, 1999).

Drama programs have been found to improve student achievement. A Chicago based nonprofit arts education organization designed Reading Comprehension through Drama (RCD), a reading program that uses drama techniques, including imagery and memory. A randomized control group design was used to assess the impact of the program on fourth grade students' reading comprehension. The overall reading improvement rates for the students taking part in the RCD program had a significantly greater rate of improvement than the control group (Rose, Parks, Androes, \& McMahon, 2000).

\section{Interdisciplinary Education.}

The Arts Education Partnership published reports on the effect of arts integration in a collection called Champions of Change: The Impact of the Arts on Learning (Fiske, 1999). Champions begins with an analysis (Catterall, Capleau, \& Iwanaga, 1999) of an extensive database compiled by the Department of Education. It showed that low-income students who were high arts participators did better in school than peers who were low arts participators. Another study (Seidel, 1999) described how the producing of a high school Shakespeare festival under the direction of theatre professionals transformed the classic works from an educational problem into a challenging adventure for students. Another study (Burton, Horowitz, \& Abeles, 1999) found evidence that transfer occurred in schools that evoked arts-related competencies in other subjects, arguing that transfer is a far more dynamic and complicated event than the conventional idea of a linear connection between previous and new learning.

Several studies related to the impact of arts integration on student achievement have been 
undertaken by the Chicago Arts Partnerships in Education. The 1999 evaluation of arts integration, included in Champions of Change, found that Chicago Arts Partners in Education (CAPE) schools, showed growth along a variety of measures of student achievement. Additionally, when compared to other schools in Chicago comprised of comparable student populations, CAPE schools attained stronger standardized test scores (Catterall \& Waldorf, 1999).

In her qualitative study, DeMoss (2002) explored how children process and understand information differently when learning through the arts. Ten volunteer teachers from eight schools in six of the partnerships participated. Participating teachers identified comparable academic units that they would teach during the year, with one unit incorporating the arts and the other using more traditional instructional approaches. Teachers then selected three students representative of their classes as a whole, including a range of students who excelled in traditional academic tasks to those who struggled, as indicated by standardized achievement test scores. The types of learning that the study found arts integration to support were in some ways unlike what teachers had anticipated. They reported that the increased engagement students demonstrated in arts units seemed to help them retain more. Students' knowledge from the arts integrated units did differ from their non-arts knowledge: it was more analytical and more oriented toward conceptual understanding than recollection of facts. DeMoss' findings imply that the arts can play a crucial role in the general nature of students' learning, offering more meaningful connections with academic work.

\section{Self-efficacy.}

As examined in previous sections, academic self-efficacy has been found to be a contributing factor to girls' interest and success in the study of science and mathematics. Drama 
has been linked to the improvement in self-efficacy. Based on a study conducted by researchers from Teachers College, Columbia University involving over 2,000 students in elementary and middle schools, significant relationships were found to exist between school arts programs and creative, cognitive, and personal competencies. Students in arts-rich schools were far more likely to view themselves as academically competent than were students in schools whose arts provisions were not rich or continuous. Students in the arts-rich schools were also far more likely to believe they did well in school, in general, particularly in language and mathematics (Burton, Horowitz, \& Abeles, 1999).

\section{The Collaborative and Experiential Nature of Drama.}

Drama is an inherently cooperative activity. Every step of the continuum from creative drama activities to fully staged theatrical productions involves the collective work of many in the pursuit of a common goal.

In a year-long study by Horn (1992), students in a New York City arts-magnet school were involved in the collaborative process of developing, writing, and performing original scripts. Qualitative inquiry evidenced growth in self-perception over the course of the year. Students also increasingly saw themselves as leaders and as important members of the class. An important aspect of this study is its collaborative nature. The teacher/researcher served as a facilitator and coach, but the products of the study were created by the students working together. In a study described in Critical Links: Learning in the Arts and Student Academic and Social Development (Deasy, 2002), a compendium of research related to arts in education, the effect of themed fantasy play on story comprehension in early elementary children was investigated. Students were divided into three groups. All groups were read a story by an adult. Each group was then exposed to a different condition for processing and exploring the story: 
thematic fantasy play, discussion, or drawing. The fantasy play group was not only the most collaborative group but also the group posting the highest levels of total story recall and story sequence recall (Pellegrini \& Gada, 1982). Pellegrini and Gada illustrated through this study that fantasy play centering on a theme requires students to accommodate to the views of others to sustain play.

In terms of experiential learning, drama provides a unique opportunity. Drama creates a dynamic context for learning because it closely resembles the experience of real life yet allows the participants to temporarily suspend reality without binding consequences (Gay \& Hanley, 1999). Drama is doing. For those teachers who want their students to derive benefit form experiential learning, infusing drama into the curriculum provides for hands-on, meaningful, lasting learning (Rubin, 2002).

Of the many experientially oriented dramatic techniques and activities, role playing is a promising one for educational research. Role playing is grounded in real world experience. Using it in the classroom encourages the students to think about their own connections to the world, and what plans they may have for the future. Using role-playing gives students a chance to explore actual options (Lens, Simons, \& Dewitte, 2002). Acting out real-life situations captures the imagination, which leads to higher-level thinking and more motivation (Hennessey, 2003).

A study by Wagner (1986) explored the effects of role playing on persuasive writing. The study involved a role-playing prewriting activity for one group, direct instruction for another, and no instruction for another. The study found that role playing in partners is more effective than direct instruction when it comes to persuasive letter writing.

The problem with research into drama in education is its quantity and quality. Klock 
(1975) reviewed literature relating to creative drama spanning the years 1890 through 1972 . His findings revealed that of 1,100 reports in the field, just $4 \%$ contained any empirical research. More recently Kardash and Wright (1987) conducted a meta-analysis of journal articles and doctoral dissertations produced from 1965 to 1984 which dealt empirically with the effects of creative drama interventions on elementary students' academic and social skills. Of the 57 studies reviewed by the researchers, only 16 included sufficient data and used appropriate variables. Of these 16 studies, only 2 used random sampling, and only 6 used an experimental research design.

\section{Conclusion}

This document seeks to show, through the literature reviewed, the potential links between (1) the existing gender gap in science and mathematics, (2) plausible reasons for it, and (3) a possible intervention. Although valid contrasting views and issues with current research exist, evidence gives merit to the proposed intervention and its potential effectiveness.

It is a matter of fact that females have fallen behind academically and professionally in the fields of science and mathematics. Reviewed studies reliably trace that lag to an attitude shift related to self-efficacy which occurs in adolescence. Research points to the potential effectiveness of collaborative, experiential, interdisciplinary methods to improve the selfefficacy of girls toward the study of math and science. The need for further research focusing on the relationship between (1) drama and (2) science and mathematics self-efficacy is clear.

One research question will be explored in this dissertation research. The question pertains to the potential use of theatre in the presentation of mathematical concepts in relation to the self-efficacy of middle school girls toward the study of mathematics.

Research Question: What is the impact on the Mathematics self-efficacy of middle school 
Academic Self-Efficacy 17

girls when mathematical concepts are presented through the use of theatrical infusion? 


\section{CHAPTER 2}

\section{Method}

This study explores the relationship between Mathematics self-efficacy in middle school girls and presentation of the material via theatrical infusion. This chapter will address the method used in the study and includes the following: (a) participant recruitment and description, (b) the research design, (c) the research instrument used, (d) the procedure, and (e) the data analysis plan.

\section{Participants}

The participants in this study were $5^{\text {th }}$ through $8^{\text {th }}$ grade girls taking part in Starring...Math. Starring...Math is an extracurricular program which provides instruction on Math concepts through the use of theatrically infused activities. Math concepts presented in the program are based on the West Virginia Content Standards and Objectives for fifth through eighth grades. Informational flyers were distributed at elementary and middle schools throughout Harrison County inviting voluntary participation. Participants were required to have parental permission prior to the start of the program.

\section{Research Design}

This study evaluated the relationship between mathematics self-efficacy and theatrical presentation of material (theatrical infusion). The independent variables were (a) Scale-Item Coverage (covered and not covered by the intervention) and (b) Repeated Testing (Pre-Test, Post-Test, and Follow-Up). The dependent variables are the measures of mathematics selfefficacy (Part One of the Mathematics Self-Efficacy Scale: Everyday Math Tasks). Thus, this was a 2x3 ANOVA with one main effect for Scale-Item Coverage (within-subjects), one main effect for Repeated Testing (within-subjects), and an interaction of Scale-Item Coverage by 
Repeated Testing.

The mathematics self-efficacy of each group at each occasion was assessed using the Mathematics Self-Efficacy Scale. A copy of this scale is located in Appendix A.

\section{Research Instrumentation}

The Mathematics Self-Efficacy Scale was used to assess middle school girls' sense of mathematics self-efficacy. This instrument was designed by Nancy E. Betz and Gail Hackett to assess one's beliefs that he or she is capable of performing math-related tasks and behaviors. The MSES contains 34 items divided into two parts: Everyday Math Tasks (18 items) and MathRelated Courses (16 items). Examinees rate each item based on a 10-point scale ranging from "No Confidence at All" to "Complete Confidence." The MSES yields three scores, one for Mathematics Task Self-Efficacy, one for Math Related School Subjects Self-Efficacy, and a Total Mathematics Self-Efficacy score. Scores are calculated by dividing the sum of the responses completed by the number of items completed. According to the scoring instructions for the Mathematics Self-Efficacy Scale, up to three items can be omitted from the instrument without affecting the validity of the instrument (Betz \& Hackett, 1989). Items 4, 9 and 12 were omitted from Part I of the instrument. Those three items were deemed too difficult for the participants to understand due to their age. This study examined scores from Part I: Everyday Math Tasks of the Mathematics Self-Efficacy Scale, excluding items 4, 9, and 12.

Betz and Hackett report internal consistency reliability coefficients of .96 for the Total scale, and .92 for both the Math Tasks and Courses subscales respectively. In addition, coefficient alpha (.92) and test-retest reliability (2-week interval) (.94) are reported (Betz \& Hackett, 1983).

\section{Procedure}


Participant scores on two groups of scale-items were examined during this study. One group of scale-items coincides with content covered during the intervention, Starring...Math. These items include numbers $1,3,5,7,8,15$, and 18 . The second group contains items relating to uncovered content and include numbers $2,6,10,11,13,14,16$, and 17 . Items were categorized as Covered or Uncovered based on their correlation with concepts included in the intervention as well as the level of depth of concept coverage. For example, item number 10 concerns the calculation of the length of time it would take to travel from point A to point B at a given speed. This problem can be solved with an algebraic equation. Algebraic concepts are included in the intervention but not at this level. This is also the case with items $6,11,16$, and 17. Items 2,13 , and 14 concern percentages and the reading of graphs. These concepts are included in the middle school mathematics curriculum but are not covered in the intervention.

Starring...Math is an after school program which presents math concepts using theatre as the mode of instruction. The math and theatre concepts used in Starring... Math were derived from the West Virginia Content Standards and Objectives Policies Policy 2520.2 and Policy 2520.11 (WV Department of Education, 2008). Math concepts addressed were in the areas of (1) numbers and operations, (2) geometry, (3) algebra, and (4) measurement. Theatre concepts addressed were (1) acting, (2) design and, (3) producing.

Participating students attended five, ninety minute sessions over the course of three weeks. The program occurred outside of regular school hours. Each session featured a different set of math and theatre concepts. Starring...Math was instructed by the investigator. The investigator administered the Mathematics Self-Efficacy Scale.

Participants' mathematics self-efficacy was evaluated three times during the study using the Mathematics Self-Efficacy Scale (MSES). The first evaluation occurred at the start of the 
program. The second occurred at the conclusion of the program. The third was two weeks after completion of the program. Upon completion of data collection, analysis was conducted using the Statistical Package for the Social Sciences version 18.0 (SPSS 18.0).

\section{Data Analysis}

One research question was explored in this dissertation research. The question pertains to the potential use of theatre in the presentation of mathematical concepts in relation to the selfefficacy of middle school girls toward the study of mathematics. The question specifically asks the following. What is the impact on the Mathematics self-efficacy of middle school girls when mathematical concepts are presented through the use of theatrical infusion? 


\section{CHAPTER 3}

Results

What is the impact on the Mathematics self-efficacy of middle school girls when mathematical concepts are presented through the use of theatrical infusion? The analyses in this chapter are directed toward answering this question. The sample consisted of 21 students, all female. Of the 21 participants, $33.3 \%(n=7)$ were in the sixth grade, $42.9 \%(n=8)$ were in the seventh grade and $23.8 \%(n=6)$ were in the eighth grade. The mean age of participants was 12.9 years. To assess impact of the intervention on participants' Mathematics self-efficacy, participants completed Part One of The Mathematics Self-Efficacy Scale. Part One of The Mathematics Self-Efficacy Scale is an 18 item questionnaire. The scale asks the participant to rate their level of confidence as to whether they believe they could successfully accomplish a task. An example of a scale item would be, "How much confidence do you have that you could successfully add two large numbers (e.g., 5379+62543) in your head." Each item is rated on a 09 scale. Some scale items directly relate to concepts covered in the intervention program. These items are referred to as "Covered Scale-Items." Some items relate to concepts not covered in the intervention. These items are referred to as "Uncovered Scale-Items." Scoring involved computing the mean score for each group of items (Covered and Uncovered). All surveys were complete and useable.

\section{Data Analysis}

The independent variables for this study were Scale-Item Coverage and Repeated Testing. The Scale-Item Coverage independent variable had two sets of scale items. One set of test items related to material covered in the workshop (Covered Scale-Items). The workshop presented mathematical concepts in a theatrical manner. Mathematical concepts covered 
included (1) numbers and operations, (2) geometry, (3) algebra, and (4) measurement. Scale items $1,3,5,7,8,15$, and 18 related to these mathematical concepts. These items are referred to as, "Covered Scale-Items."

The other set of test items had to do with material not covered in the workshop (Uncovered Scale-Items). These items related to concepts other than those presented and included items $2,6,10,11,13,14,16$, and 17. These items are referred to as, "Uncovered ScaleItems." According to the scoring instructions for the Mathematics Self-Efficacy Scale, up to three items can be omitted from the instrument without affecting the validity of the instrument (Betz \& Hackett, 1989). Items 4, 9 and 12 were omitted from Part I of the instrument. Those three items were deemed too difficult for the participants to understand due to their age. The Repeated Testing independent variable was composed of a (1) Pre-Test, (2) Post-Test, and (3) Follow-Up. A chart of all test items and their classification as (1) Covered, (2) Uncovered, or (3) Omitted is presented in Table 1.

The dependent variable was the test score. Participants completed Part One of The Mathematics Self-Efficacy Scale at three testing occasions (1) at the start of the workshop (PreTest), (2) at the completion of the workshop (Post-Test), and (3) two weeks after the completion of the workshop (Follow-Up). Thus, each participant had six scores. On the Pre-Test, each participant had a mean score (range 0-9) for the Covered Scale-Items and a mean score (range 09) for the Uncovered Scale-Items. On the Post-Test, each participant had a mean score (range 09) for the Covered Scale-Items and a mean score (range 0-9) for the Uncovered Scale-Items. On the Follow-Up test, each participant has a mean score (range 0-9) for Covered Scale-Items and a mean score (range 0-9) for Uncovered Scale-Items. The means and standard deviations for these six conditions are shown in Table 2. 


\section{Table 1}

The Mathematics Self-Efficacy Scale Item Classification

\section{$\underline{\text { Scale Item }}$}

1. Add two large numbers

in your head

2. Determine the amount of

Sales tax on a clothing purchase

3. Figure out how much material

to buy in order to make curtains

4. Determine how much interest you will end up paying on a $\$ 675$

loan over 2 years at $143 / 4 \%$ interest

5. Multiply and divide using a calculator

6. Compute your car's gas mileage

7. Calculate recipe quantities for a dinner for 3 when the original recipe is for 12 people

8. Balance your checkbook without a mistake

9. Understand how much interest you will earn on your savings account in 6 months, and how that interest is computed

10. Figure out how long it will take to travel from Columbus to

Chicago driving at $55 \mathrm{mph}$

11 . Set up a monthly budget for yourself taking into account how much money you earn, bills to pay, personal expenses, etc

12. Compute your income taxes for the year

13. Understand a graph accompanying an article on business profits

\section{Classification}

Covered

Uncovered

N/A

Covered

Omitted

Measurement

Geometry

Number Operations

N/A

Covered

Number Operations

Uncovered

N/A

Covered

Measurement

Number Operations

Covered

Number Operations

Omitted

N/A

Uncovered

N/A

Uncovered

N/A

Omitted

N/A

Uncovered

N/A 
14. Figure out how much you would save if there is a $15 \%$ mark-down

on an item you wish to buy

15. Estimate your grocery bill in your head as you pick up items

16. Figure out which of 2 summer jobs is the better offer: one with a higher salary but no benefits; the other with a lower salary but with room, board, and travel expenses included

17. Figure out the tip on your part of a dinner bill total split 8 ways

18. Figure out how much lumber you need to buy in order to build a set of bookshelves
Uncovered

N/A

Covered

Number Operations

Uncovered

N/A

Uncovered

N/A

Covered

Measurement

Geometry

Number Operations 
Table 2

Means and Standard Deviations for Covered vs. Uncovered Scale-Items crossed with Pre vs. Post vs. Follow-Up Repeated Measures

Source

$M$

$S D$

Main Effect: Repeated Testing

Pre-test

3.09

0.86

Post-test

4.47

1.16

Follow-up

4.17

0.97

Main Effect: Scale-Item Coverage

Covered

4.59

1.08

Uncovered

3.23

0.78

Interaction: Testing by Concept Coverage

Pre-test-Covered

0.81

Post-test-Covered

4.83

0.77

Follow-up-Covered

2.59

0.83

Pre-test-Uncovered

3.59

0.57

Post-test-Uncovered

3.52

0.73

Follow-up-Uncovered

0.59 
To assess the research question, an overall within-subjects Analysis of Variance (ANOVA) was computed. The results of this $2 \times 3$ ANOVA with one main effect for Scale-Item Coverage (within-subjects), one main effect for Repeated Testing (within-subjects), and an interaction of Scale-Item Coverage by Repeated Testing are shown in Table 3. For the ScaleItem Coverage main effect (Covered vs. Uncovered), there was a statistically significant difference, $F(1,20)=211.10, p<.01$. The ANOVA also tested the Repeated Testing main effect (Pre-test vs. Post-test vs. Follow-up). That analysis revealed a significant difference among the three times of measurement, $F(2,40)=69.57, p<.01$. A multiple comparisons test was not computed because the hypothesis was that the theatrical intervention would yield test differences. At all three of these means, both the Covered and Uncovered Items scores are included. Thus, even though an overall gain or loss across time periods may exist, this significant finding does not allow differentiation of Repeated Testing and effects of Scale-Item Coverage (Covered vs. Uncovered). Accordingly, one must examine the interaction of the two independent variables to provide a fair test of the hypothesis. 
Table 3

Analysis of Variance for Covered vs. Uncovered Scale Items crossed with Pre vs. Post vs. Follow-up Testing

\begin{tabular}{|c|c|c|c|c|c|}
\hline Source & $d f$ & $S S$ & $M S$ & $F$ & $p$ \\
\hline \multicolumn{6}{|l|}{ Main Effect: } \\
\hline Covered-Uncovered Test Items & 1 & 58.22 & 58.22 & 211.10 & $<.01$ \\
\hline Error Term & 20 & 5.52 & 0.28 & & \\
\hline \multicolumn{6}{|l|}{ Main Effect: } \\
\hline Pre-Post-Follow-up Testing & 2 & 43.98 & 21.99 & 69.57 & $<.01$ \\
\hline Error Term & 40 & 12.65 & 0.32 & & \\
\hline \multicolumn{6}{|l|}{ Interaction: } \\
\hline Testing by Items & 2 & 3.00 & 1.50 & 5.04 & $<.01$ \\
\hline Error Term & 40 & 11.94 & 0.30 & & \\
\hline
\end{tabular}


The ANOVA assessed the interaction of the two independent variables (Scale-Item Coverage by Repeated Testing). It yielded a statistically significant interaction effect, $F(2,40)=$ $5.04, p<.01$. The six means and standard deviations for this interaction are presented in Table 2 . Most notable would be comparisons of the means of the Post-Test Covered Items versus PostTest Uncovered Items and Follow -Up Covered Items versus Follow-Up Uncovered Items. The difference between scores at Pre-Test (both covered and uncovered) would not be a test of the hypothesis that the theatrical intervention would produce a test difference. These means are, however, included in the table. It is also important to note that the ideal situation for the study would have been for both Pre-Test scores (Covered and Uncovered) to be essentially equal. They were not. There was a difference in reported self-efficacy in favor of Covered Scale-Items at the Pre-Test occasion. This anomaly is discussed further in Chapter 4.

Results from Tukey's post-hoc test considering interaction between both main effects, shown in Table 4, revealed the following. Scores for Covered Scale-Items differed significantly from Pre-Test to Post-Test $(p<.01)$. Scores for Covered Scale-Items differed significantly from Pre-Test to Follow-Up $(p<.01)$. Scores for Covered Scale-Items did not differ significantly from Post-Test to Follow-Up $(p>.01)$. These findings are important to note as they show an increase in self-efficacy from the start to the completion of the program. The fact that these scores did not differ significantly from Post-Test to Follow-Up indicates that much of this gain was retained. Scores for Uncovered Scale-Items differed significantly from Pre-Test to PostTest $(p<.01)$. Scores for Uncovered Scale-Items differed significantly from Pre-Test to FollowUp $(p<.01)$. Scores did not differ significantly for Uncovered Scale-Items from Post-Test to Follow-Up $(p>.01)$. These scores provide evidence of a gain in self-efficacy even for concepts not specifically addressed in the intervention. Like those for the Covered Scale-Items, the gain 
was retained from Post-test to Follow-Up. A significant difference existed between the scores for Covered Pre-Test versus the Uncovered Pre-Test $(p<.01)$. A significant difference $(p<.01)$ was revealed between scores for Covered Post-Test and Uncovered scores at each testing time (Pre, Post, and Follow-Up). A significant difference $(p<.01)$ also existed between scores for Covered Follow-Up and Uncovered scores at each testing time (Pre, Post, and Follow-Up). 
Academic Self-Efficacy 31

Table 4

Tukey Test of Mean Differences for Pairwise Interactions

\begin{tabular}{lllllll}
\hline & $\begin{array}{l}\text { Pre-test } \\
\text { Covered }\end{array}$ & $\begin{array}{l}\text { Post-test } \\
\text { Covered }\end{array}$ & $\begin{array}{l}\text { Follow-up } \\
\text { Covered }\end{array}$ & $\begin{array}{l}\text { Pre-test } \\
\text { Uncovered }\end{array}$ & $\begin{array}{l}\text { Post-test } \\
\text { Uncovered }\end{array}$ & $\begin{array}{c}\text { Follow-up } \\
\text { Uncovered }\end{array}$ \\
\hline Pre-test Covered & 0 & $1.75^{* *}$ & $1.23^{* *}$ & $1.01^{* *}$ & $0.01 \mathrm{NS}$ & $0.08 \mathrm{NS}$ \\
Post-test Covered & & 0 & $0.52 \mathrm{NS}$ & $2.76^{* *}$ & $1.76^{* *}$ & $1.83^{* *}$ \\
Follow-up Covered & & 0 & $2.24^{* *}$ & $1.24^{* *}$ & $1.31^{* *}$ \\
Pre-test Uncovered & & & 0 & $1.00^{* *}$ & $0.93^{* *}$ \\
Post-test Uncovered & & & & 0 & $.07 \mathrm{NS}$ \\
Follow-up Uncovered & & & & & 0 \\
\hline
\end{tabular}

$* * p<.01$

$\mathrm{NS}=$ not significant 
The research question asked, "what is the impact on the Mathematics self-efficacy of middle school girls when mathematical concepts are presented through the use of theatrical infusion?" The data analysis has shown that, in this study, the theatrical presentation of mathematical concepts did have a positive effect on the self-efficacy of the participants. This impact is visually represented in Figure 1. 
Figure 1. Mean Differences in Covered Items vs. Uncovered Items at Each Testing Occasion

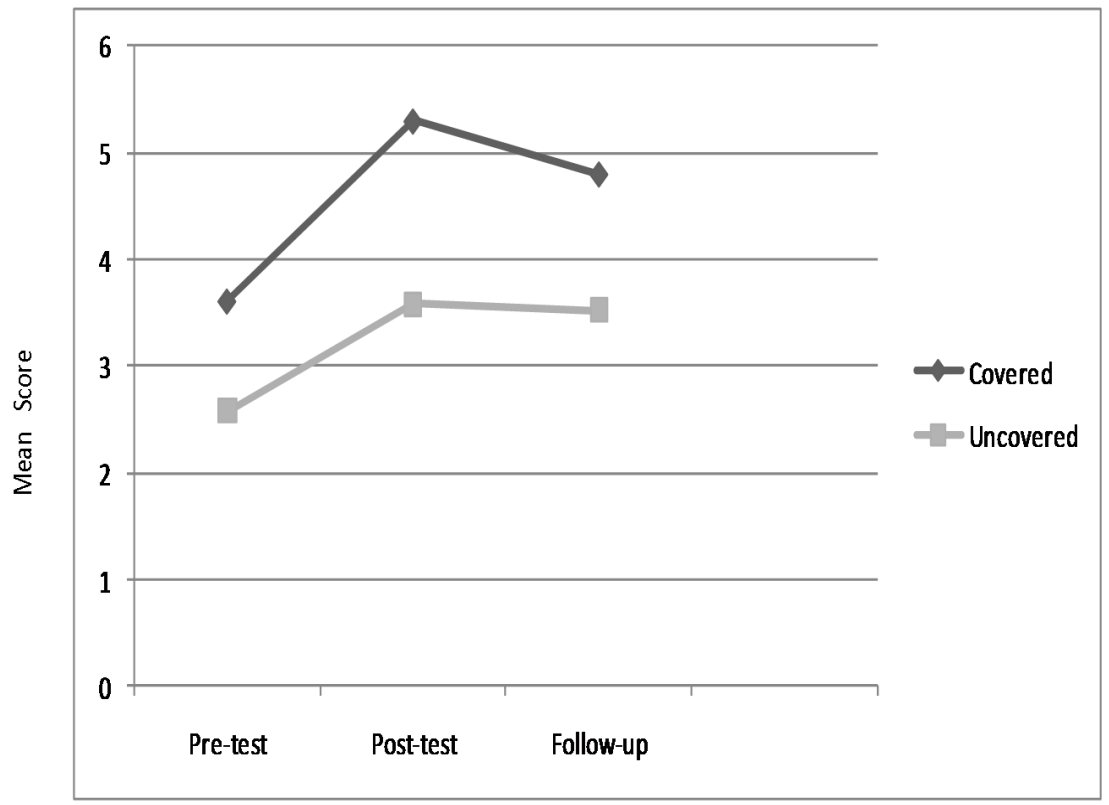




\section{CHAPTER 4}

Discussion and Conclusions

\section{Summary}

The purpose of this study was to determine the impact of the presentation of material via theatrical infusion on the Mathematics self-efficacy of middle school girls. A group of girls in the sixth, seventh, and eighth grades participated in Starring...Math, a five week program which presented mathematical concepts through theatre activities. The program was instructed by the investigator. The participants completed the Mathematics Self-Efficacy Scale on three testing occasions (1) before the start of the program (Pre-Test), (2) after the completion of the program (Post-Test), and (3) two weeks after the completion of the program (Follow-Up). Items on the scale were divided into two groups (1) those that addressed concepts covered in the program (Covered Scale-Items) and (2) those that did not address concepts covered in the program (Uncovered Scale-Items). Scores on each group of test items at each testing occasion were analyzed.

The participants' rating of mathematics self-efficacy increased significantly on the Covered Scale-Items from Pre-Test to Post-Test, without a significant change from Post-Test to Follow-Up. For the Uncovered Scale-Items, there was a statistically significant change from Pre-Test to Post-Test, with no significant change from Post-Test to Follow-Up.

\section{Discussion}

Research has shown that females typically express a lower confidence level in their mathematics and science abilities, despite there being no achievement difference (Pajaras, 2002). This phenomenon is known as the confidence gap and seems to develop in the middle school years. In their report, Trends in Educational Equity of Girls and Women, the National Center for 
Educational Statistics (2000) reported that a virtually equal number of fourth grade boys and girls report positive feelings toward math and science. By the eighth grade, the results are far different. Eighth-grade girls are less likely to think they are good at math or science. For girls especially, self-perceptions play an important role in science and math achievement. Self-esteem and academic achievement begin to decline in females during middle school years (Backes, 1994). This study targeted females in the sixth through eighth grades, years typically known as "middle school" (in addition to fifth grade). The results of the Pre-Test scores on the Mathematics Self-Efficacy Scale for all items (Covered and Uncovered) indicate a low level of self-efficacy toward mathematics with a Pre-Test mean score of 3.09 on a 0-9 scale.

Academic self-efficacy can be positively impacted in girls through a variety of means. There is much we know about the way females learn best. Owens and Straton (1980) found that girls prefer cooperation, open-ended activities, and organized activities, while boys prefer competition and individualism. Girls are more successful in math and science programs that incorporate a cooperative, hands-on approach than in programs that stress competition and individual learning (National Council for Research on Women, 2001). Girls like to work in cooperative groups and discuss the task at hand (Fennema \& Leder, 1990). An interdisciplinary focus is also important in the math and science education of girls (National Council for Research on Women, 2001).

A collaborative, experiential, interdisciplinary learning method should be employed to reach the female population during the crucial middle school years in order to ensure equity and diversity in upper level science and mathematics courses, university programs, and the professional world. Such a thing already exists, ready to be adapted to an instructional setting. Drama is inherently collaborative and experiential. Virtually every part of the theatrical process 
is based in team work and cooperation. Actors must work together to create meaning from the words of the playwright. Technicians work together to create the look and feel of a production. Drama that incorporates improvisation involves the creation of character and story from the ideas of the group. In terms of experiential learning, drama creates a dynamic context for learning because it closely resembles the experience of real life, yet allows the participants to temporarily suspend reality without binding consequences (Gay \& Hanley, 1999).

Theatre and drama have long been a component of interdisciplinary education. Research has shown that children process and understand information differently when learning in through the arts. Increased engagement and retention of information has been reported (DeMoss, 2002). This integration often occurs in a literature or history class. Many literary works and biographies of historical characters have come to life on elementary, middle, and high school stages throughout the years. Mathematics, however, is not a typical choice for theatrical infusion.

Starring...Math strategies handle concepts in a social context. This method is supported by the theories of John Dewey. He felt that isolation of concepts from a social concept was an obstacle to learning. Starring...Math provides what Dewey believed were crucial to method, reflection, and learning. These essentials include an experiential learning situation and the opportunity to engage in problem solving (Bernstein, 1966).

Starring...Math is a five week program that fully integrates mathematics and theatre based concepts. Each session combines at least one theatre concept with at least one mathematics concept. For example, in one session, students learned about both set design and geometry. They were tasked with creating a set for a given children's story using various polyhedra to represent the set pieces they deemed necessary. They had to plan which shape would work for which piece. In many cases, combinations of shapes were necessary to create 
their set designs. After their plan was devised, each group of participants then created a three dimensional set model of their plan using paper polyhedra. The activities of this session were collaborative, experiential, and interdisciplinary, as were all sessions.

Each participant was tested before the start of the five week program, at its conclusion, and then again two weeks later. There was a statistically significant increase in the mathematics self-efficacy of the participants of the intervention on both the Covered and Uncovered ScaleItems. The ideal situation for the study would have been for both Pre-Test scores (Covered and Uncovered) to be essentially equal. They were not. There was a difference in reported selfefficacy in favor of Covered Scale-Items at the Pre-Test occasion. Another potential limitation is the fact that there are eight Uncovered Scale-Items and seven Covered Scale-Items as opposed to each group being equal. These anomalies do not, however, diminish the findings of the study. The study sought to explore whether or not a theatrically infused presentational method would have an impact on the academic self-efficacy toward the study of mathematics in middle school girls. The data showed a significant improvement in self-efficacy from the start to the completion of the program on scale-items relating to material covered in the intervention. The data also showed a lesser but still significant difference on the scale-items relating to material not covered in the intervention. This difference indicates that there was a positive impact on the participants' self-efficacy toward mathematical concepts in general as opposed to only on those concepts directly addressed in the intervention. This global increase can be attributed to the theatrical context of the instruction.

\section{Implications for Further Research}

The results of this study warrant further examination of the connection between mathematics self-efficacy and the theatrical presentation of material in the following ways. 
- A follow-up study should be conducted with a larger sample over a longer period of time. Studying more participants will give an even more accurate picture of the impact theatrical infusion can have on the target population. A longer study period will give the investigator and participants more time to address more concepts and to achieve a greater level of infusion and concept coverage.

- The extra curricular nature of the initial study should also be explored. It would be of interest to replicate the study in a classroom as opposed to an extracurricular setting to determine if that context had an impact on the results.

- The relationship between self-efficacy and achievement should also be explored. The initial study focused solely on self-efficacy. A logical question would center on whether or not increased self-efficacy will translate to increased achievement in Mathematics.

- The current study did not compare the impact of theatrical infusion on males versus females. A follow up study would be warranted to further explore this topic.

\section{Conclusions}

Based on the results of this study, it appears that the theatrical presentation of material can have a statistically significant positive effect on the academic self-efficacy toward the study of mathematics in middle school girls. The findings of the study have implications for instructional strategies and further research. 


\section{References}

American Association of University Women. (1998). Gender gaps: Where schools still fail our children. Washington, DC: Author.

American Psychological Association. (2006). Congressional briefings focus on science education. Washington, DC: Author.

Austin, T (2005). Goals 2000--the Clinton administration education program . Retrieved October 3, 2008, Web site: http://www.nd.edu/ rbarger/www7/goals200.html

Backes, J. S. (1994). Bridging the gender gap: Self concept in the middle grades. Schools in the Middle, 30, 19-23.

Bandura, A. (1986). Social foundations of thought and action: A social cognitive theory. Englewood Cliffs, NJ: Prentice Hall.

Bandura, A. (1994). Self efficacy. In V.S. Ramachaudran (Ed.), Encyclopedia of human behavior (Vol.4, pp.71-81). New York: Academic Press. (Reprinted in H. Friedman[Ed.], Encyclopedia of mental health: Academic Press, 1998).

Bernstein, R. (1966). John Dewey, The great American thinkers series. New York: Washington Square Press.

Betz, N., \& Hackett, G. (1993). The relationship of mathematics self-efficacy expectations to the selection of science-based college majors. Journal of Vocational Behavior, 23, 329-345.

Betz, N., \& Hackett, G. (1989). Mathematics self efficacy scale test booklet. Retrieved July 13, 2008, from http://www.mindgarden.com

Blank, R. K., \& Langesen, D. (1999). State indicators of science and mathematics education 1999. State-by-state trends and new indicators from the 1997-98 school year. Washington, DC: CCSSO, State Education Assessment Center. 
Bolton, G. (1985). Changes in thinking about drama in education. Theory Into Practice, $24(3), 151-157$.

Borzak, L. (Ed.). (1981). Field study. A source book for experiential learning, Beverly Hills, CA: Sage Publications.

Bruner, J. (1985). Vygotsky: An historical and conceptual perspective. Culture, communication, and cognition: Vygotskian perspectives, 21-34. London: Cambridge University Press.

Burton, J., Horowitz, R., \& Abeles, H. (1999). Learning in and through the arts: Curriculum implications. In E. B. Fiske (Ed.), Champions of change: The impact of the arts on learning. (Available from the Arts Education Partnership, One Massachusetts Avenue, NW, Washington, DC 2001, http://www.aeparts.org/PDF\%20Files/ChampsReport.pdf.)

Bybee, R., \& Kennedy, D. (2005). Math and science achievement. Science, 307(481). Retrieved October 1, 2006, from http://www.sciencemag.org/cgi/content/summary/307/5709/481

Catterall, J. S., Capleau, R., \& Iwanaga, J. (1999). Involvement in the arts and human development. In E. B. Fiske (Ed.), Champions of change: The impact of the arts on learning. (Available from the Arts Education Partnership, One Massachusetts Avenue, NW, Washington, DC 2001, http://www.aeparts. org/PDF\%20Files/ChampsReport.pdf)

Catterall, J., \& Waldorf, L. (1999). The Chicago Arts Partnerships in Education Evaluation. In E.B. Fiske (Ed.), Champions of change: The impact of the arts on learning (pp. 47-62). Washington, D.C.: Chief Council of State School Officers. Chambers, B., \& Abrami, P. C. (1991). The relationship between student team learning 
outcomes and achievement, causal attributions, and affect. Journal of Educational Psychology. 83, 140-146. Reprinted in S. Towson. (Ed.). (1992). Educational psychology: Readings for the Canadian context, pp. 242-256. Peterborough, Ontario: Broadview Press.

Consortium of National Arts Education Associations. (2002). Authentic connections: Interdisciplinary work in the arts. Washington, D.C..: Author

Day, P., \& McCabe, R. (1997). Remedial education: A social and economic imperative. Issue Paper.Washington, D.C.: American Association of Community Colleges.

Deasy, R. (Ed). (2002). Critical links: Learning in the arts and student academic and social development. Washington, DC: National Endowment for the Arts, United States Department of Education.

DeMoss, K. (2002). How arts integration supports student learning: Students shed light on the connections. CAPE Research in Arts Integrated Education, Retrieved September, 5, 2006, from http://www.capeweb.org/demoss.pdf

Educational Broadcasting Corporation. (2004). Workshop: Inquiry-based learning. Retrieved October 6, 2006, from http://www.thirteen.org/edonline/concept2class/constructivism/index.html

Etzkowitz, H., Kemelgor, C., \& Uzzi, B. (2000). Athena unbound: The advancement of women in science and technology. Cambridge, MA: Cambridge University Press.

Fennema, E. \& Leder, G. (Eds.) (1990). Mathematics and gender. New York, NY: Teachers College Press.

Fiske, E. B. (Ed.). (1999). Champions of change: The impact of the arts on learning. Arts Education Partnership, One Massachusetts Avenue, NW, Washington, DC 2001. 
http://www.aep-arts.org/PDF\%20Files/ChampsReport.pdf

Gay, G., \& Hanley, M. (1999). Multicultural empowerment in middle school social studies through drama pedagogy. Clearing House, 72(6), 364-370.

Gokhale, A. (1995). Collaborative learning enhances critical thinking. Journal of Technology Education. Retrieved September 20, 2006 from: http://www.2/7/01.http://scholar.lib.vt.edu/ejournal/JTE/v7n1/gokhale.jte- v7n1.html

Gonzalez, D. (2006, March). Arts-infused learning: Artistic pathways for at-risk learners. Paper presented at the UNESCO World Conference on Arts Education, Lisbon, Portugal.

Hakeem, S. A. (2001). Effect of experiential learning in business statistics. Journal of Education for Business, 77, 95-99.

Hennessey, B. (2003). The social psychology of creativity. Scandinavian Journal of Educational Research, 47(3), 253-271.

Horn, J. (1992). An exploration into the writing of original scripts by inner city high school drama students (ERIC: ED 366 957). National Arts Research Center, National Endowment for the Arts, United States Department of Education.

Hyde, J., Lindberg, S., Linn, M., Ellis, A., \& Williams, C. (2008). Gender similarities characterize math performance. Science, 321, 494-495.

Johnson, D.W., Mariyama, G., Johnson, R., Nelson, D., \& Skon, L. (1981). The effects of cooperative, competitive and individualistic goal structures on achievement: A meta analysis. Psychological Bulletin 89, 47-62.

Kardash, C. A. M., \& Wright, L. (1987). Does creative drama benefit elementary school students: A meta-analysis. Youth Theatre Journal, 1, 11-18.

Klock, M. F. (1975). Creative drama. A selected and annotated bibliography. Washington, D.C.: 
American Theatre Association.

Kolb, D. A., \& Fry, R. (1975). Toward an applied theory of experiential learning. Inc. Cooper (Ed.) Theories of group process (pp. 35-36). London.

Kolb, D. A. (1984). Experiential learning. Englewood Cliffs, NJ: Prentice Hall.

Kraft, R. J. (1995). Towards a theory of experiential education. In R. Kraft \& M. Sakofs (Eds.). The theory of experiential education (pp. 7-38). Boulder, CO: Association for Experiential Education.

Labinowicz, (Ed.) (1980). The Piaget primer: Thinking, learning, teaching. Menlo Park, CA. Addison-Wesley Publishing Co.

Lens, W., Simons, J., \& Dewitte, S. (2002). From duty to desire: The role of students' future time perspective and instrumentality perceptions for study of motivation and self-regulation. Greenwich, CT: Information Age Publishing, Inc.

Ma, X., \& Willms, J. D. (1999). Dropping out of advanced mathematics: How much do students and school contribute to the problem? Educational Evaluation and Policy Analysis, 21, 365-383.

McKinney, K. (2006). Active Learning. Retrieved November 6, 2006, from Illinois State University Web site: http://www.cat.ilstu.edu/additional/tips/newActive.php Meredith, F. (2005, March 5). Science's gender deficit. Irish Times. Retrieved September 20, 2006 from http://www.ireland.com/newspaper/features/2005/0309

Meyers, C., \& Jones, T. B. (1993). Promoting active learning: Strategies for the college classroom. San Francisco: Jossey-Bass Publishers.

National Center for Educational Statistics. (2000). Trends in educational equity for girls and 
women. Washington DC: Author.

National Commission on Mathematics and Science Teaching for the $21^{\text {st }}$ Century. (2000). Before it's too late. Washington, D.C.: Author

National Council for Research on Women. (2001). Balancing the equation: Where are women \& girls in science, engineering, and technology? Washington, DC: Author.

National Mathematics Advisory Panel (2008). Foundations for success: Report of the National Mathematics Advisory Panel. Washington, DC: Author

National Science Foundation. (1996). Indicators of science and mathematics education. Arlington, VA: Author.

Owens, L. C., \& Straton, R. G. (1980). The development of a cooperative, competitive and individualized learning preference scale for students. British Journal of Educational Psychology, 50, 147-161.

Okebukola, P.A. (1986). The influence of preferred learning styles on cooperative learning in science. Science Education, 70, 509-517.

Pajares (2002). Self-efficacy beliefs in academic contexts: An outline. Retreived 10/14/2005, from http://des.emory.edu/mfp/efftalk.html.

Pellegrini, A., \& Gada, L. (1982) The effects of thematic-fantasy play training on the development of children's story comprehension. Amercian Educational Research Journal, 19(3), 443-452.

Robbins, B. (1988). Creative dramatics in the language arts classroom. (Report No. EDO-CS 88-07). Bloomington, IN: Indiana University School of Education. (ERIC Document Reproduction Service No. 29740288).

Rose, D., Parks, M, Androes, K., \& McMahon, S. (2000). Imagery based learning: 
Improving elementary students' reading comprehension with drama techniques. Journal of Educational Research, 94(1), 55-64.

Rubin, J. (2002). Integrating drama/theatre into the curriculum. Retrieved November 5, 2005 from http://www.svsu.edu/ rubin/lessons.htm

Seidel, S. (1999). Stand and unfold yourself. In E. B. Fiske (Ed.), Champions of change: The impact of the arts on learning. (Available from the Arts Education Partnership, One Massachusetts Avenue, NW, Washington, DC 2001, http://www.aeparts.org/PDF\%20Files/ChampsReport.pdf.)

Smith, M. (May, 1997). Paulo Freire. Retrieved November 25, 2006, from the Encyclopedia of Informal Education, Web site: http://www.infed.org/thinkers/et-freir.htm

Smith, M. (2001). David A. Kolb on experiential learning, Retrieved March 24, 2004 from the Encyclopedia of Informal Education, Web site: http://www.infed.org/b_explrn.htm.

Sonnert, G. (1998). Digging deeper: The present status of women scientists suggest avenues of further research. Paper presented at the New York Academy of Sciences conference "Choices and successes: women in science and engineering." Retrieved November 1, 2006 from http://www.sciam.com/explorations/1998/051898women/issues.html

Tippins, D. J. (1991, April). The relationship of science self-efficacy and gender to ninth grade students' intentions to enroll in elective science courses. Paper presented at the annual meeting of the American Educational Research Association, Chicago, IL. United States Department of Education, 2005 U.S. Department of Education. (2005). National Center for Educational Statistics, National Assessment of Educational Progress, 1990, 1992, 1996, 2002, and 2003 Mathematics Assessments. Retrieved 
September 10, 2008, from <http://nces.ed.gov/>.

United States Department of Labor. (2000). 20 million jobs: January, 1993-November, 1999, report by the Council of Economic Advisors and the Chief Economist.Washington, D.C.: Author.

Vygotsky, L. (1978). Mind in society: The development of higher psychological processes. Cambridge, MA: Harvard University Press.

Wagner, B. (1986). The effects of role playing on written persuasion: An age and channel comparison of fourth and eighth graders. Unpublished doctoral dissertation, University of Illinois at Chicago.

West Virginia Department of Education. (2008). Content Standards and Objectives Policies. Retrieved October 16, 2008 from West Virginia Department of Education Web site: http://wvde.state.wv.us/policies/csos.html.

Wheeler, R., \& Ryan, F. L. (1973). Effects of cooperative and competitive classroom environments on the attitudes and achievement of elementary school students engaged in social studies inquiry activities. Journal of Educational Psychology, 65, $402-407$.

White, P. E. (1992). Women and minorities in science and engineering: An update. Washington, DC: National Science Foundation. 


\section{Appendix A}

Mathematics Self-Efficacy Scale 


\section{Mathematics Self-Efficacy Scale}

Test Booklet

by

Nancy E. Betz

and

Gail Hackett

Distributed by Mind Garden, Inc. info@mindgarden.com

www.mindgarden.com

Copyright ( 1993 Nancy E. Betz and Gail Hackett. All rights reserved. 
There are two parts to this instrument: Part I and Part II.

Please read all instructions and respond carefully and completely.

Score:

Please provide the following information:

Name or I.D.

Date Age

Gender (Please Circle): $\quad \mathbf{F} \quad \mathbf{M}$

\section{Part I: Everyday Math Tasks}

Please indicate how much confidence you have that you could successfully accomplish each of these tasks by circling the number according to the following 10-point confidence scale.

Part I

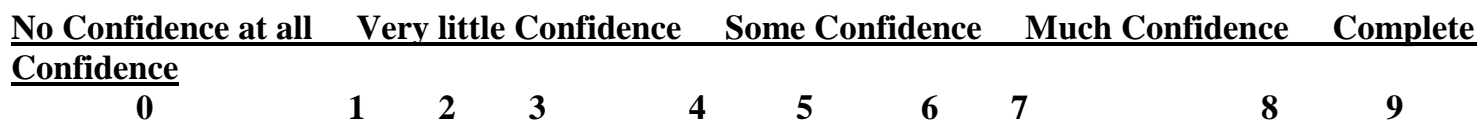

How much confidence do you have that you could successfully:

1. Add two large numbers (e.g., 5379

$+62543)$ in your head.

$\begin{array}{llll}0 & 1 & 2 & 3\end{array}$

2. Determine the amount of sales

tax on a clothing purchase.

3. Figure out how much material to buy in order to make curtains. 0

$\begin{array}{lllllllll}1 & 2 & 3 & 4 & 5 & 6 & 7 & 8 & 9\end{array}$

4. Determine how much interest you will end up paying on a $\$ 675$ loan over 2 years at $143 / 4 \%$ interest. $\begin{array}{llllllllll}\ldots 0 & 1 & 2 & 3 & 4 & 5 & 6 & 7 & 8 & 9\end{array}$

5. Multiply and divide using a calculator.

6. Compute your car's gas mileage.

7. Calculate recipe quantities for a dinner for 3 when the original recipe is for 12 people.

$\begin{array}{lllllllllll}0 & 1 & 2 & 3 & 4 & 5 & 6 & 7 & 8 & 9\end{array}$

8. Balance your checkbook without a mistake.

....0

9. Understand how much interest you will earn on your savings account in 6 months, and how that interest is computed. 0

\section{Go on to next page.}


Part I (Cont.)

No Confidence at all Very little Confidence Some Confidence Much Confidence Complete Confidence

$\begin{array}{llllllllll}\mathbf{0} & 1 & 2 & 3 & 4 & 5 & 6 & 7 & 8 & 9\end{array}$

How much confidence do you have that you could successfully:

10. Figure out how long it will take to travel from Columbus to Chicago driving at $55 \mathrm{mph}$.... 0

$\begin{array}{lllllllll}1 & 2 & 3 & 4 & 5 & 6 & 7 & 8 & 9\end{array}$

11. Set up a monthly budget for yourself taking into account how much money you earn, bills to pay, personal expenses, etc ...0

12. Compute your income taxes

for the year. ...0

13. Understand a graph accompanying an article on business profits.

14. Figure out how much you would save if there is a $15 \%$ mark-down on an item you wish to buy. .... ... 0

15. Estimate your grocery bill in your head as you pick up items. 0

16. Figure out which of 2 summer jobs is the better offer: one with a higher salary but no benefits; the other with a lower salary but with room, board, and travel expenses included.

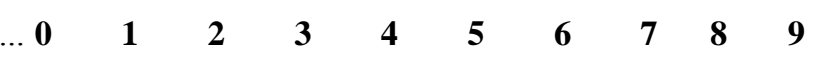

17. Figure out the tip on your part of a dinner bill total split 8 ways. ... 0

18. Figure out how much lumber you need to buy in order to build a set of bookshelves.

\section{Go on to Part II.}




\section{Part II: Math Courses}

Please rate the following college courses according to how much confidence you have that you could complete the course with a final grade of "A" or "B". Circle your answer according to the 10-point scale below:

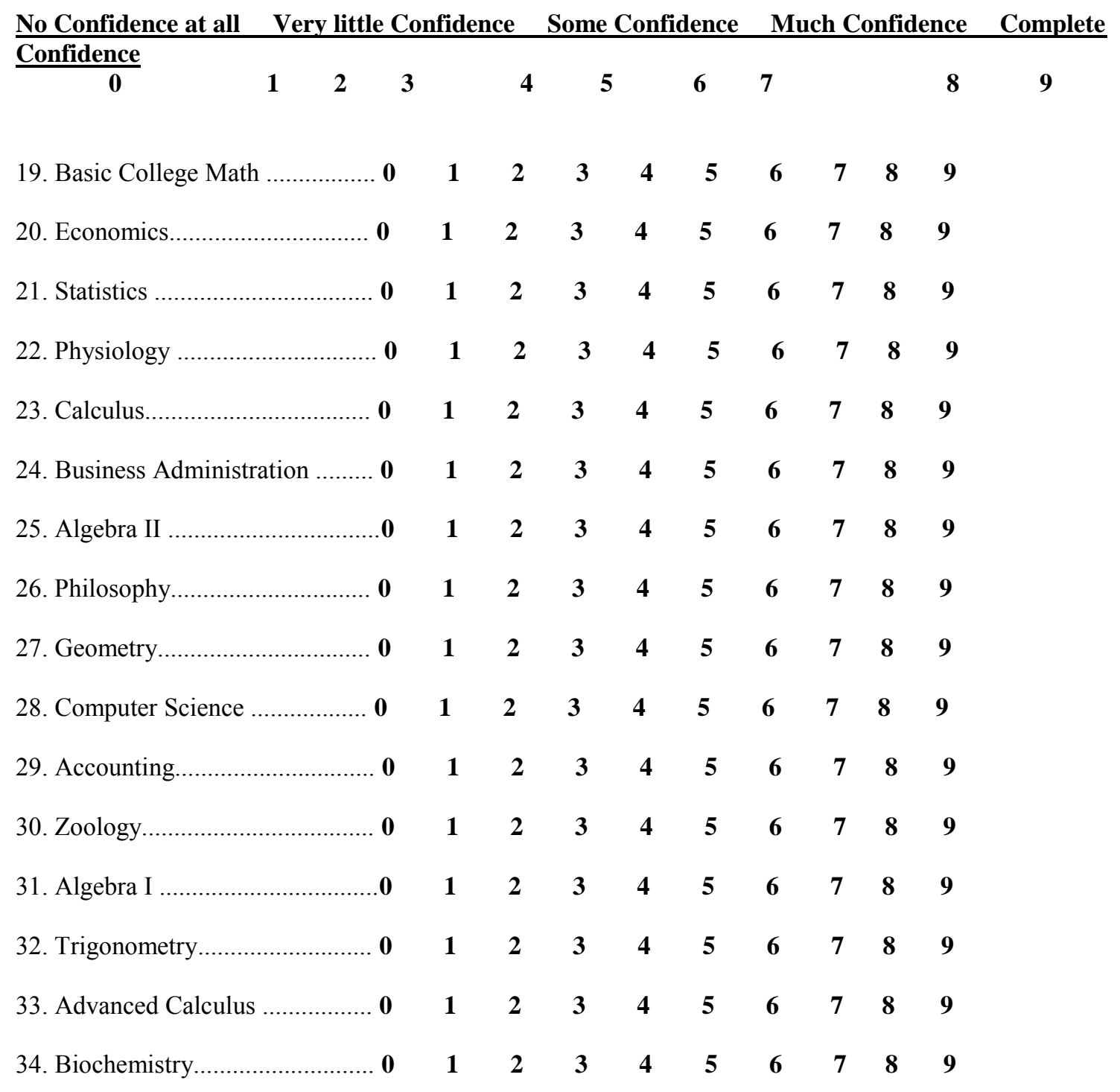

You have now completed the Mathematics Self-Efficacy Scale. Thank you for your cooperation. 


\section{Appendix B}

Starring...Math a series of theatrically infused math lessons for 5-8 grades 


\section{Starring...Math}

a series of theatrically infused math lessons for 5-8 grades

\section{$\underline{\text { Session } 1}$}

Math Topic Area: Numbers and Operations, Algebra

Theatre Topic Area: Acting

WV Math Standard addressed:

Standard 1: Numbers and Operations

Through communication, representation, reasoning and proof, problem solving, and making connections within and beyond the field of mathematics, students will demonstrate an understanding of numbers, ways of representing numbers, and relationships among numbers and number systems, demonstrate meanings of operations and how they relate to one another, and compute fluently and make reasonable estimates.

Standard 2: Algebra

Through communication, representation, reasoning and proof, problem solving, and making connections within and beyond the field of mathematics, students will demonstrate understanding of patterns, relations and functions, represent and analyze mathematical situations and structures using algebraic symbols, use mathematical models to represent and understand quantitative relationships, and analyze change in various contexts.

WV Theatre Standard addressed:

Standard 2: Acting

Students will act by developing, communicating, and sustaining characters in improvisations and informal or formal productions.

\section{$\underline{\text { Session Activities }}$}

\section{Activity 1}

\section{Solve the Mystery}

Description:

Students will create and perform a script from a given work. Completion will require solving mathematical word problems to construct the ending of the piece.

Materials:

-Copies of The Cuckoo Caper (which can be found at www.scholastic.com)

-Paper for each group 
Procedure:

-introduce the lesson components

-participants are divided into two groups

-participants will read The Cuckoo Caper in story format

-each group works together to solve the math riddle in the story

-each group identifies and describes the theatrical elements in the story:

Characters

Setting

Events

-participants brainstorm ideas regarding elements of the story

-play improvisation game in which students act out the story "tag team" style

-begin at the beginning of the story, assigning roles

-when a new character needs to enter, call a student's name and they jump into the action

-as the story progresses, call out a character name and a student's name and that student assumes that character

-continue to the end of the story

-each group develops a script version of The Cuckoo Caper

-work with each group briefly to establish basic blocking, then give them 15 minutes to

"rehearse"

-each group performs their scene for the others 


\section{$\underline{\text { Session } 2}$}

Math Topic Area: Geometry, Numbers and Operations

Theatre Topic Areas: Set Design, Acting

WV Math Standard addressed:

Standard 1: Numbers and Operations

Through communication, representation, reasoning and proof, problem solving, and making connections within and beyond the field of mathematics, students will demonstrate an understanding of numbers, ways of representing numbers, and relationships among numbers and number systems, demonstrate meanings of operations and how they relate to one another, and compute fluently and make reasonable estimates.

Standard 3: Geometry Through communication, representation, reasoning and proof, problem solving, and making connections within and beyond the field of mathematics, students will analyze characteristics and properties of two- and three-dimensional geometric shapes and develop mathematical arguments about geometric relationships, specify locations and describe spatial relationships using coordinate geometry and other representational systems, apply transformations and use symmetry to analyze mathematical situations, and solve problems using visualization, spatial reasoning, and geometric modeling.

WV Theatre Standards addressed:

Standard 2: Acting

Students will act by developing, communicating, and sustaining characters in improvisations and informal or formal productions.

Standard 3: Designing and Producing

Students will design and produce by conceptualizing and realizing artistic interpretations for informal or formal productions.

\section{$\underline{\text { Session Activities }}$}

\section{Activity 1 Body Alphabet}

Description:

Students will explore theatrical space awareness and cooperation in creation as well as right, 
obtuse and acute angles through the following Theatre warm-up/game.

Materials:

-none

Procedure:

-introduce lesson components

-as a large group, determine how many and what types of angles are present in each letter of the alphabet -participants break into groups of four -the group leader describes a letter in terms of the number of lines and number and kind of angles it contains. -groups collectively decide what letter the group leader has described and then execute the letter with their bodies on the floor

\section{Activity 2 \\ Shape A Face}

Description:

Students use a variety of simple and more advanced shapes including rhombus, trapezoid, hexagon, pentagon, octagon, triangle, circle, square to create a mask for a given emotion.

Students then use the masks to create improvisations.

Materials:

-mask form for each participant

-glue

-various cut out shapes (rhombus, trapezoid, hexagon, pentagon, triangle, circle, octagon, square)

-list of shapes required for each design

-photos of various facial expressions

-mirrors

Procedure:

-introduce lesson components

-participants spend some time in front of a mirror exploring what facial features indicate the emotions: sad, mad, happy, surprised

-show participants photographs of examples of each emotion and discuss similarities and differences in shapes created with the eyes, mouth, eyebrows, etc.

-assign each participant an emotion (sad, mad, happy, surprised)

-a variety of shapes are spread out on a table -participants are given a list of how many of each shape they can gather (they must be able to identify the shapes to know how many of each to collect) -participants use their collected shapes to construct a mask for a given emotion (sad, mad, happy, surprised)

-participants are grouped so that each group contains a combination of mask designs -each group creates and performs an improvisation using their created masks 


\section{$\underline{\text { Session } 3}$}

Math Topic Area: Geometry

Theatre Topic Areas: Set Design

WV Math Standard addressed:

Standard 3: Geometry Through communication, representation, reasoning and proof, problem solving, and making connections within and beyond the field of mathematics, students will analyze characteristics and properties of two- and three-dimensional geometric shapes and develop mathematical arguments about geometric relationships, specify locations and describe spatial relationships using coordinate geometry and other representational systems, apply transformations and use symmetry to analyze mathematical situations, and solve problems using visualization, spatial reasoning, and geometric modeling.

WV Theatre Standards addressed:

Standard 2: Acting

Students will act by developing, communicating, and sustaining characters in improvisations and informal or formal productions.

Standard 3: Designing and Producing

Students will design and produce by conceptualizing and realizing artistic interpretations for informal or formal productions.

\section{$\underline{\text { Session Activities }}$}

\section{Activity 1 \\ Shape a Set}

Description:

Students will design a set for a scene from a story of their choice. They will execute a model of the set using the polygons and polyhedra they construct.

Materials:

-copies of various stories such as folktales and fairy tales -polygon and polyhedra patterns (which can be found at http://www.korthalsaltes.com/) -scissors

-tape

-glue

-foamboard 
Procedure:

-introduce the lesson components

-participants are directed to construct various polygons and polyhedral using the provided patterns

-divide the participants into groups of three or four

-each group chooses a scene from a story for which to create a set using the polygons and polyhedra by deciding on necessary components and assessing their comparability to the available shapes

-groups build a set using the previously constructed shapes 


\section{$\underline{\text { Session } 4}$}

Math Topic Area: Measurement

Theatre Topic Area: Theatrical Makeup

WV Math Standard addressed:

Standard 4: Measurement

Through communication, representation, reasoning and proof, problem solving, and making connections within and beyond the field of mathematics, students will demonstrate understanding of measurable attributes of objects and the units, systems, and processes of measurement, and apply appropriate techniques, tools and formulas to determine measurements.

WV Theatre Standard addressed:

Standard 3: Designing and Producing

Students will design and produce by conceptualizing and realizing artistic interpretations for informal or formal productions.

\section{$\underline{\text { Session Activities }}$}

\section{Activity 1}

Makin' Make-Up

Description:

Students will design and execute a theatrical makeup design using creams they make by following and adjusting a given recipe

Materials:

Recipe for cream makeup

Ingredients and tools:

- beeswax

- mineral oil

- nontoxic crayon

- measuring spoons (various sizes)

- heat resistant custard cup

- plastic bag

- hammer

- paper towels

- small saucepan

- knife 
- spoon

-Put about one teaspoon beeswax in the custard cup

-Add three tablespoons mineral oil to the cup

-Put the crayon in a plastic bag and smash it with the hammer

-Put the smashed crayon in the cup

-Place the custard cup in the small saucepan that contains enough water to reach a level of about 1.5 inches up the side of the custard cup

-Put the setup over medium heat

-Stir occasionally until the waxes are melted and the color is evenly spread throughout the liquid

-Turn off heat and allow to cool for five to ten minutes

Procedure:

-introduce lesson components

-students create a makeup diagram for a fantasy design

-divide students into three groups. Each will make white and a different color cream

-groups follow the "recipe", choosing the correct measurement instruments and executing

the correct measurements following the recipe for the individual group color and

doubling it for the white

-students will execute their designs using the creams 


\section{$\underline{\text { Session } 5}$}

Math Topic Area: Numbers and Operations, Algebra, Measurement

Theatre Topic Area: Acting, Design and Producing

WV Math Standard addressed:

Standard 1: Numbers and Operations

Through communication, representation, reasoning and proof, problem solving, and making connections within and beyond the field of mathematics, students will demonstrate an understanding of numbers, ways of representing numbers, and relationships among numbers and number systems, demonstrate meanings of operations and how they relate to one another, and compute fluently and make reasonable estimates.

Standard 2: Algebra

Through communication, representation, reasoning and proof, problem solving, and making connections within and beyond the field of mathematics, students will demonstrate understanding of patterns, relations and functions, represent and analyze mathematical situations and structures using algebraic symbols, use mathematical models to represent and understand quantitative relationships, and analyze change in various contexts.

Standard 4: Measurement

Through communication, representation, reasoning and proof, problem solving, and making connections within and beyond the field of mathematics, students will demonstrate understanding of measurable attributes of objects and the units, systems, and processes of measurement, and apply appropriate techniques, tools and formulas to determine measurements.

WV Theatre Standard addressed:

Standard 3: Designing and Producing

Students will design and produce by conceptualizing and realizing artistic interpretations for informal or formal productions.

\section{$\underline{\text { Session Activities }}$}

\section{Activity 1}

Now We're Cookin'

Description:

Participants will design and execute a set for a television cooking show

Materials: 
-table

-two video cameras

-bowls

-measuring cups and spoons

-cupcake pans

-measuring tape

-spike tape

Procedure:

-introduce lesson components

-participants are divided into three groups

-participants are given instructions that they are to take on the role of set design teams -participants are given the instructions that they are to create set for a television cooking show -participants must create the set by reducing a given design to fit the given space -participants must place cameras at given angles

\section{Activity 2}

Now We're Cookin' continued

\section{Description:}

Participants will rehearse and perform a television cooking show

Materials:

Bowls

Measuring cups and spoons

Cupcake pans

Cupcake ingredients:

- 2 1/4 cups all purpose flour

- 1 1/3 cups sugar

- 3 teaspoons baking powder

- $1 / 2$ teaspoon salt

- $1 / 2$ cup shortening

- 1 cup milk

- 1 teaspoon vanilla

- 2 large eggs

-Preheat oven to 350 degrees. Line cupcake pans with paper liners.

-Combine flour, sugar, baking powder, and salt in a large mixing bowl. Add shortening, milk, and vanilla.

-Beat for 1 minute on medium speed.

-Scrape side of bowl with a spatula.

-Add eggs to the mixture.

-Beat for 1 minute on medium speed. 
-Scrape bowl again.

-Beat on high speed for 1 minute 30 seconds until well mixed.

-Spoon cupcake batter into paper liners until $1 / 2$ to $2 / 3$ full.

-Bake for 20 to 25 minutes or until toothpick inserted in center comes out clean.

-Cool 5 minutes in pans then remove and place on wire racks to cool completely.

-Once cupcakes are completely cooled, frost with your favorite frosting recipe or decorate as you desire.

Procedure:

-groups assign roles of performers, director, camera operators, etc.

-groups create a script for their cooking show

-to create the script, groups must take a given cupcake recipe and calculate measurements for a double and triple batch to be included in the dialogue

-groups follow the "recipe", choosing the correct measurement instruments and executing

the correct measurements to perform their show about baking cupcakes 
VITAE

Aimee L. Richards

Nutter Fort, West Virginia

EDUCATION

Roosevelt-Wilson High School 1989

Bethany College

1993

Fine Arts

West Virginia University

2003

Master of Arts of Liberal Studies

Educational Psychology and Theatre

West Virginia University

2010

Bachelor of Arts

Educational Psychology

\section{John $\mathrm{H}$.

